\title{
Notes on the genus Entoloma s.l. in the Northwest of the Iberian Peninsula (XI): a new species in subgenus Entoloma
}

\author{
Blanco-Dios JB
}

Centro de Formación e Experimentación Agroforestal de Lourizán. Consellería do Medio Rural. Xunta de Galicia. P.O. Box 127. 36003 Pontevedra, Spain

Blanco-Dios JB 2021 - Notes on the genus Entoloma s.l. in the Northwest of the Iberian Peninsula (XI): a new species in subgenus Entoloma. Studies in Fungi 6(1), 64-70, Doi 10.5943/sif/6/1/2

\begin{abstract}
Entoloma cedeirense, a new species in subgenus Entoloma, is described from in Galicia (NW of Spain). A detailed macro and micromorphological descriptions, drawings and a discussion with closely related taxa of subgenus Entoloma is provided.
\end{abstract}

Key words - Agaricales - Basidiomycota - Entolomataceae - Spain - Taxonomy

\section{Introduction}

The genus Entoloma sensu lato (Entolomataceae) contains at least 2000 species worldwide.Traditionally it is considered one genus with around 15 subgenera, or split into smaller genera (Noordeloos et al. 2018).

During the study of the mycological flora of the A Capelada (A Coruña, Spain), an unidentified tricholomatoid species of Entoloma was collected in grassland margin, on ultra-basic soil. The new species belongs to the sect. Entoloma, due to tricholomatoid carpophores, nonhygrophanous, non-striate pileus, spores (sub)isodiametrical, pileipellis an ixocutis made up of cylindrical hyphae with distinctly gelatinized walls, with intracellular pigment and presence of clamp connections (Noordeloos 1981).

An extensive literature review of the European and extra-European species of this subgenus and section (Horak 1980, Noordeloos 1981, 1992, 2004, Gates \& Nooordeloos 2007, Horak 2008, Largent et al. 2008, Noordeloos \& Gates 2012, Morgado et al. 2013, Largent et al. 2014, Kokkonen 2015, Brandrud et al. 2018, Noordeloos et al. 2018) confirmed that no other published species matched the particular combination of characters exhibited by our collections. Due to its unique combination of macroscopic and microscopic characteristics, a new species for science is proposed in this contribution.

\section{Materials \& Methods}

\section{Morphological analysis}

The specimens were collected, documented and preserved using standard protocols (Noordeloos 1992, 2004). Morphological descriptions are based on fresh materials collected. Microscopic observations were recorded on fresh or dried material with standard methods, using sections mounted in water, after staining with $1 \%$ Congo red in water and a short pre-treatment in a $5 \% \mathrm{KOH}$ solution, or in $10 \% \mathrm{NH}_{4} \mathrm{OH}$. Basidiospores measurements (length, width, Q (quotient length/width), $\mathrm{Qm}=$ average quotient) were taken for 30 basidiospores, excluding hilar appendix. 
Extreme values have been noted between brackets when they represented no more than $10 \%$ of the measurements. Basidia dimensions are based on 10 basidia. Microscopic structures were drawn with help of a drawing tube. Author citations follow the IPNI Authors Website (http://www.ipni.org/ipni/authorsearchpage.do) and the Index Fungorum Authors of Fungal Names Website (http://www.indexfungorum.org/authorsoffungalnames.htm). The new species name was deposited in MycoBank (http://www.mycobank.org/DefaultPage.aspx) while the facesoffungi number was registered as mentioned in Jayasiri et al. (2015). The collected and studied material is deposited in the mycological herbarium LOU-Fungi (Centro de Investigación Forestal de Lourizán, Consellería de Medio Rural, Pontevedra, Spain).

\section{Results}

\section{Taxonomy}

Entoloma cedeirense Blanco-Dios sp. nov.

Figs $1-5$

MycoBank number: MB 835477; Facesoffungi number: FoF 09537

Etymology - cedeirense, the specific epithet refers to the type locality of the species (Cedeira, Spain).

Diagnosis - Habitus tricholomatoideus. Pileus 28-33 $\mathrm{mm}$ latus, primo ab globosus ad ovoideus, deinde convexus vel expansus, non hygrophanus, non traslucente striatus, ab ochraceogriseus ad atrobrunneus, fibrillosus. Lamellae ab cremeae ad luteo-roseae. Stipes 52-63 mm longus, 9-15 mm latus, cylindraceus vel subcylindraceus, clavatus ad basim, ab albidus ad ochraceus, fibrillosus. Caro ab alba ad ochracea, ex parte mutabile exposita. Odor fortiter stercoris et/vel herba fermentata et leviter rapus, pertinax. Sapor herbaceus et leviter amarus, ingratus. Sporae 5.5-7 (8) $\mu \mathrm{m}$ longae $\times$ 5-6.5 (7) $\mu \mathrm{m}$ latae, $\mathrm{Q}=1-1.1$ (1.15), $\mathrm{Qm}=1.07$, isodiametricae, 6-9angulatae. Basidia tetrasporigera, clavata, fibulata. Acies lamellarum homogenea. Cystidia desunt. Caulobasidia tetrasporigera, clavata, praesertim ad apicem stipitis, sparsa. Caulocystidia 10-24 $\times$ 5.5-12 $\mu \mathrm{m}$, lecithiformia, rostrata, subsphaerostipitata, utriformia et forma irregularis vel intermedius, praecipue ad apicem stipitis, sparsa. Pileipellis cutis hyphis cylindraceis vel subcylindraceis, 1-9 $\mu \mathrm{m}$ latis, subcutis elementis inflatis vel subcylindraceis, 30-70 $\mu \mathrm{m}$ longus, 9$16 \mu \mathrm{m}$ latus. Pigmentis intracellularis granularis vel minute incrustans. Fibulae praesentes. In pratis, in ultrabasic solo.

Holotype - Spain, A Coruña, Cedeira, Régoa, in grassland margin, on ultra-basic soil, 29 October 2019, J.B. Blanco-Dios (LOU-Fungi 21046).

Basidiomata medium sized, tricholomatoid. Pileus $28-33 \mathrm{~mm}$ broad, initially globose to ovoid, then convex to nearly plane, often slighty umbonate, with undulating marginal zone, not hygrophanous, not translucently striate, shiny, with a polished surface, ochre-gray to ochre-brown in the beginning, brown to dark brown with age. Lamellae moderately distant, broad, ventricose, subdecurrent in the young stage, cream to yellowish when young, then yellow-pinkish, with concolorous, eroded edge. Stipe 52-63 $\times 9-15 \mathrm{~mm}$, cylindrical to subcylindrical with clavate base, solid, with scattered ochre spots, the rest cream or whitish, finely fibrillose. Context cartilaginous, crunchy, brittle, white, changing to cream, pale ochre to ochre when exposed. Smell strongly (especially at the pileus) of manure and/or fermented grass and slightly to turnip and is persistent. Taste herbaceous, slightly rough, unpleasant. Exsiccata smells strongly of celery or julianne soup. Spore print pink.

Basidiospores 5.5-7 (8) $\times$ 5-6.5 (7) $\mu \mathrm{m}, \mathrm{Q}=1-1.1$ (1.15), $\mathrm{Qm}=1.07$, isodiametrical, rounded, thin-walled with many weak angles (6-9). Basidia 25-43 × 7-11 $\mu \mathrm{m}, 4$-spored, clavate, clamped, sterigmata up to $7 \mu \mathrm{m}$ long. Lamella edge fertile. Cystidia absent. Hymenophoral trama subregular, made up of subcylindrical to inflated elements, 40-99 × 3-14 $\mu \mathrm{m}$. Pileipellis 2-layered, suprapellis an ixocutis of 1-9 $\mu \mathrm{m}$ wide, cylindrical or subcylindrical hyphae; subpellis made up of inflated or subcylindrical elements, $30-70 \times 4-16 \mu \mathrm{m}$; gradually passing to pileitrama, which is regular, made up of inflated or cylindrical hyphae, 32-90 × 10-19 $\mu \mathrm{m}$. Pigment brownish, 
intracellular, granular, diffuse in pileipellis and upper trama, especially in suprapellis, layer in which hyphae with incrusting pigment are observed. Stipitipellis a cutis of narrow, cylindrical or subcylindrical hyphae, 1.5-11 $\mu \mathrm{m}$ wide, caulobasidia 15-30 $\times 6-9 \mu \mathrm{m}$, 4-spored, clavate, sterigmata up to $4 \mu \mathrm{m}$ long, sparse, especially in upper part of stipe, caulocystidia versiform, 10-24 $\times 5.5-12 \mu \mathrm{m}$, lecithiform, rostrate, subsphaeropedunculate, utriform and irregular or intermediate shapes, scattered at apex of stipe, rare in the central zone. Clamp-connections present in all tissues.

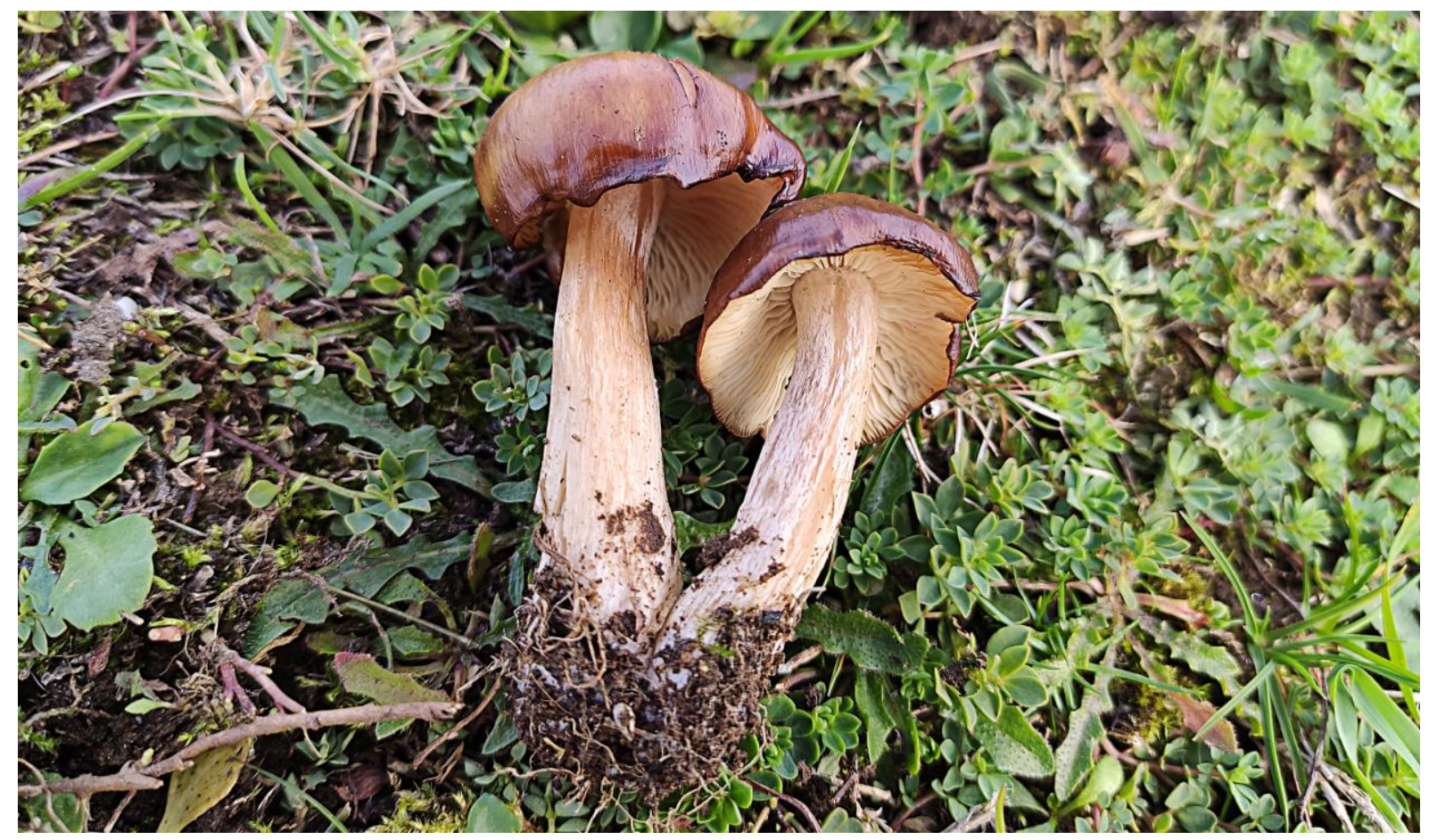

Fig. 1 - Entoloma cedeirense (LOU-Fungi 21046, holotype).

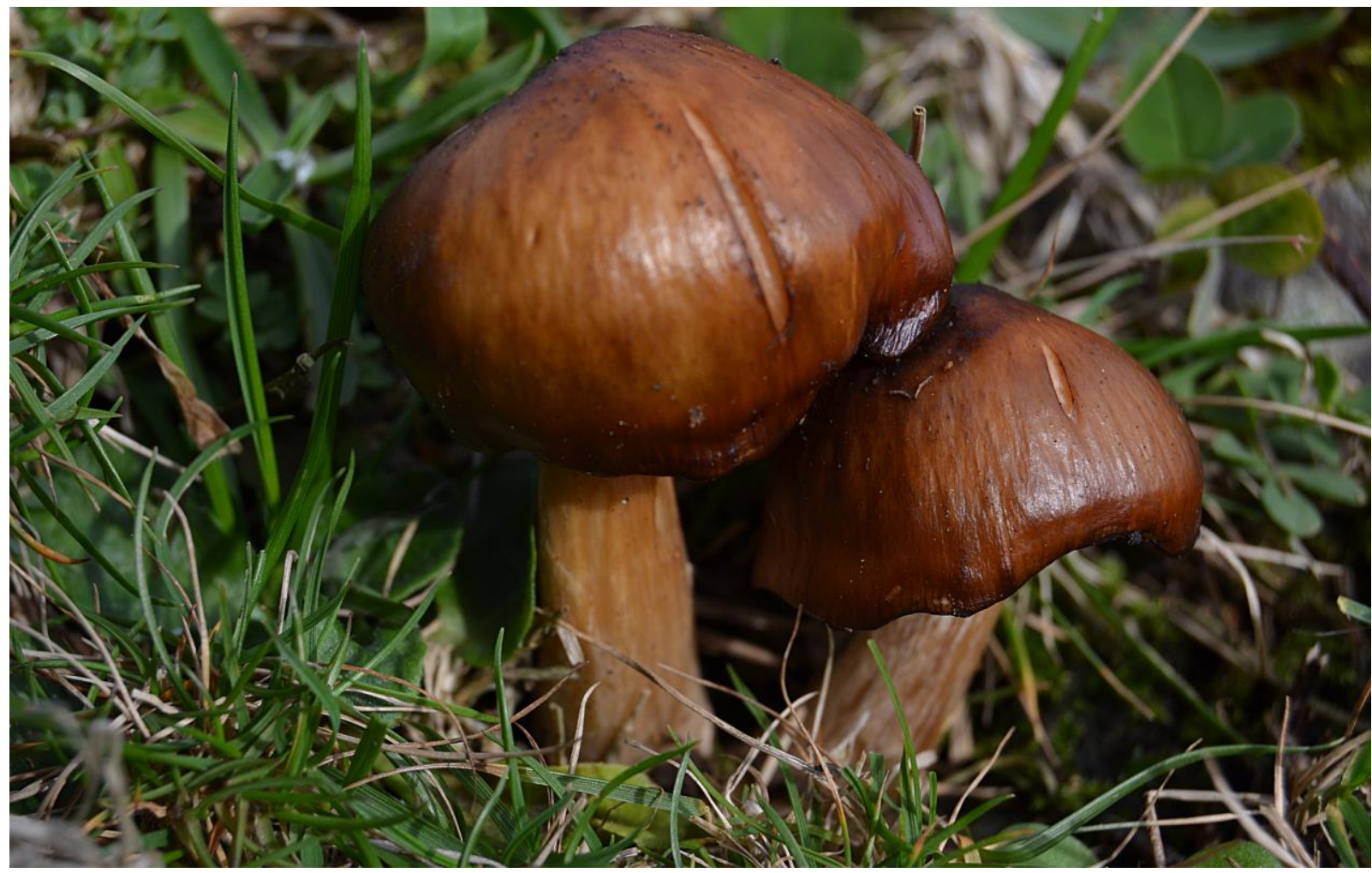

Fig. 2 - Entoloma cedeirense (LOU-Fungi 21046, holotype). 


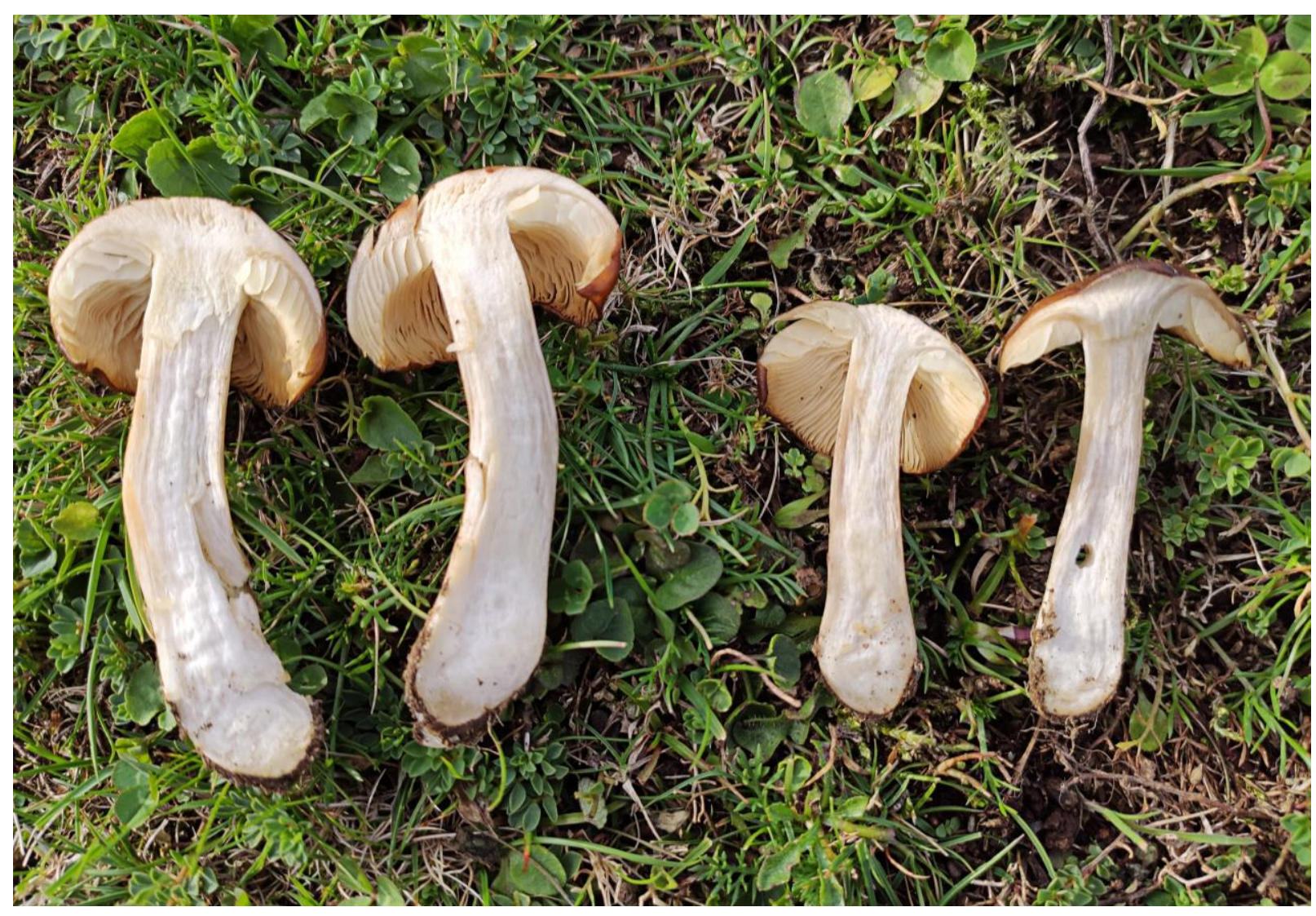

Fig. 3 - Entoloma cedeirense (LOU-Fungi 21046, holotype).

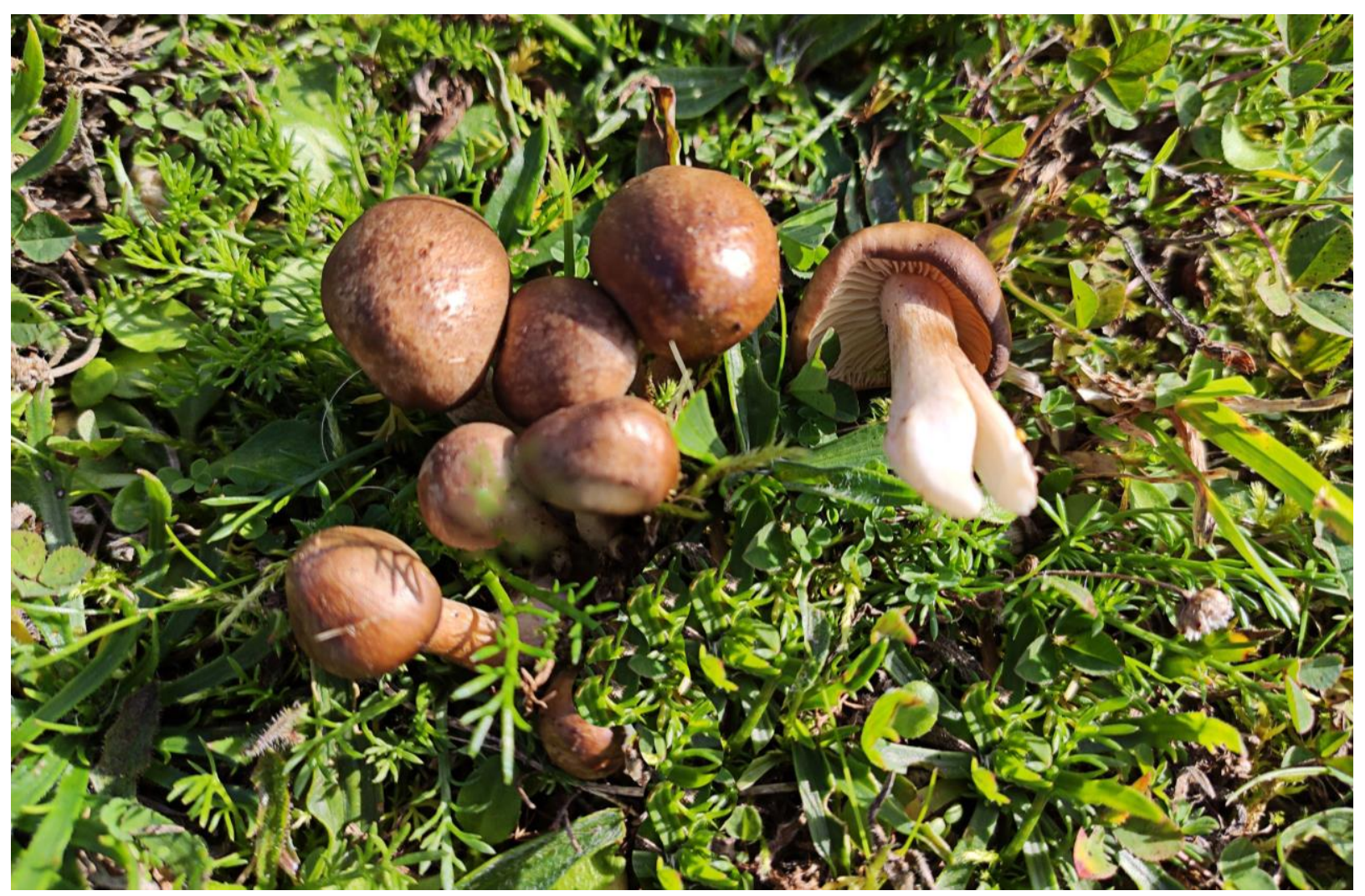

Fig. 4 - Entoloma cedeirense (LOU-Fungi 21045). Inmature basidiomata.

Known distribution - So far only known from the type locality in Cedeira (A Coruña, Spain). 
Material examined - Spain, A Coruña: Cedeira, Régoa, 29TNJ8238, $520 \mathrm{~m}$, in grassland margin, on ultra-basic soil, 26 October 2019, J.B. Blanco-Dios \& Asociación Micolóxica Andoa (LOU-Fungi 21045); ibidem, 29 October 2019, J.B. Blanco-Dios (LOU-Fungi 21046, holotype).

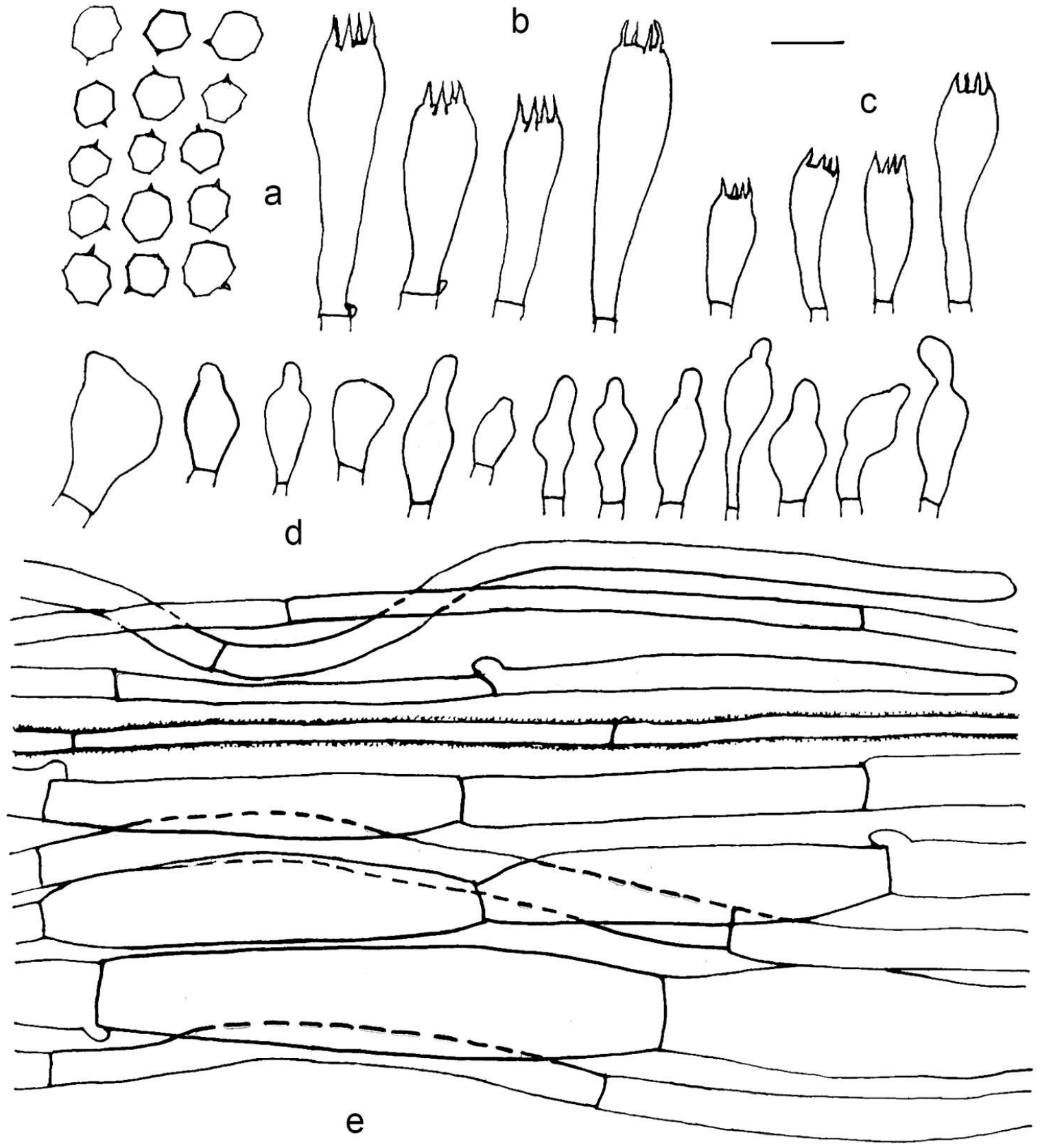

Fig. 5 - Entoloma cedeirense (LOU-Fungi 21046, holotype). a Basidiospores. b Basidia. c Caulobasidia. d Caulocystidia. e Pileipellis. Scale bar $=10 \mu \mathrm{m}$.

Notes - Entoloma cedeirense is distinct from other known Entoloma species in its strong persistent odor of manure and/or fermented grass and slightly to turnip, (exsiccata smells strongly of celery or julianne soup), herbaceous taste, unpleasant, basidiospores size (5.5-7 (8) × 5-6.5 (7) $\mu \mathrm{m}, \mathrm{Q}=1-1.1(1.15))$, isodiametric, weakly angled, versiform caulocystidia and habitat on grassland, on ultra-basic soil.

Morphologically similar species are compared and discussed here. The closest European taxa is Entoloma sinuatum and differs by a less brightly coloured lamellae with a quite different yellow tinge, acidulous-nauseating or more farinaceous-rancid odor, nasty taste, much larger, differently 
shaped, thick-walled and distinctly angled basidiospores $(8-11 \times 7-9.5 \mu \mathrm{m}, \mathrm{Q}=1-1.3)$, and habitat in deciduous forest (Noordeloos 1992).

Among the extra-European species of the same section, the closest taxa include E. cerinum E. Horak, described from New Zealand (Horak 2008), E. praeluteum Corner \& E. Horak, described from Malaysia (Horak 1980), E. manganaense G.M. Gates \& Noordel. and E. mathinnae G.M. Gates, B.M. Horton \& Noordel., described from Tasmania (Gates \& Noordeloos 2007, Gates et al. 2009), E. flavifolium Peck, E. luridum Hesler, E. subsinuatum Murrill and E. whiteae Murrill, described from North America (Morgado et al. 2013).

Entoloma cerinum differs from E. cedeirense by having a very dark brown pileus, yellowish lamellae turning dark pink with age, unpleasant odor, taste not distinctive, clampless hyphae and habitat in broadleaf podocarp forest (Horak 1980, 2008). Entoloma praeluteum is characterized by a yellow pileus, stipe and context, farinaceous smell and habitat in forest of Eugeissona sp. (Horak 1980). Entoloma manganaense can be distinguished by its dark red-brown pileus, deep yellow lamellae, blue stipe, odour none, mild taste, basidiospores 6-8.5 $\times 5.5-7.5 \mu \mathrm{m}$ and habitat in wet sclerophyll forest litter (Gates \& Noordeloos 2007). Entoloma mathinnae is differs by a pale brown pileus, bright yellow gills, white stipe or with slight blue-violaceous tinges, smell and taste indistinct, basidiospores 6.5-8 $\times 6-8 \mu \mathrm{m}$ and habitat in wet Eucalyptus delegatensis rainforest and in Eucalyptus obliqua wet sclerophyll forest (Gates et al. 2009). Distinctly pigmented pileus, slightly farinaceous smell and taste, relatively thick-walled, clearly angled basidiospores $(7-9 \times$ 6.5-7.5 (8) $\mu \mathrm{m}, \mathrm{Q}=1.1-1.3)$ and habitat on Quercus woods distinguishes E. flavifolium. Almost white basidioma, bright yellow gills, indistinct odor, basidiospores 6.5-8.5 $\times 6-8.5 \mu \mathrm{m}$ and habitat makes E. luridum distinct. Entoloma subsinuatum differs from the new taxon by pale colored basidiomata, yellow tinged lamellae only when young, strong, farinaceous smell, nasty rancid taste, basidiospores 7.3-8.6 (9.4) $\times 6.7-8.0 \mu \mathrm{m}$ and habitat close to coniferous and deciduous trees. Entoloma whiteae is well characterized by the slightly hygrophanous pileus, strongly farinaceousrancid to somewhat alkaline smell, taste farinaceous-rancid, basidiospores 7-9.6 $\times 6.5-8.5 \mu \mathrm{m}, \mathrm{Q}=$ 1.1-1.4 and habitat in mixed deciduous forest (Morgado et al. 2013).

\section{Acknowledgements}

The author is grateful to Amancio Castro (Pontevedra) for technical assistance. The Asociación Micolóxica Andoa (Cambre, A Coruña) are gratefully acknowledged for collaboration. Two anonymous reviewers are thanked for helpful suggestions. We express our sincere thanks to the director and members of the Centro de Investigación Forestal de Lourizán (Consellería do Medio Rural, Xunta de Galicia) for conserving the herbarium LOU-Fungi and for their help.

\section{References}

Brandrud TE, Bendiksen E, Jordal JB, Weholt $\varnothing$ et al. 2018 - Entoloma species of the rhodopolioid clade (subgenus Entoloma; Tricholomatinae, Basidiomycota) in Norway. Agarica 38, 21-46.

Gates GM, Noordeloos ME. 2007 - Preliminary studies in the genus Entoloma in Tasmania - I. Persoonia 19, 157-226.

Gates GM, Horton BM, Noordeloos ME. 2009 - A new Entoloma (Basidiomycetes, Agaricales) from Tasmania. Mycotaxon 107, 175-179.

Horak E. 1980 - Entoloma (Agaricales) in Indomalaya and Australasia. Beih. Nova Hedwigia 65: $1-352$.

Horak E. 2008 - Agaricales of New Zealand 1: Pluteaceae (Pluteus, Volvariella), Entolomataceae (Claudopus, Clitopilus, Entoloma, Pouzarella, Rhodocybe, Richoniella). Fungi of New Zealand.Volume 5. Fungal Diversity Research Series 19, 1-305.

Jayasiri SC, Hyde KD, Ariyawansa HA, Bhat J et al. 2015 - The Faces of Fungi database: fungal names linked with morphology, phylogeny and human impacts. Fungal Diversity 74(1): 3-18 Doi 10.1007/s13225-015-0351-8 
Kokkonen K. 2015 - A survey of boreal Entoloma with emphasis on the subgenus Rhodopolia. Mycol. Progress 14, 1-116.

Largent DL, Henkel TW, Aime MC, Baroni TJ. 2008 - The Entolomataceae of the Pakaraima Mountains of Guyana I: four new species of Entoloma s.str. Mycologia 100 (1), 132-140.

Largent DL, Bergemann SE, Abell-Davis SE. 2014 - Entoloma species from New South Wales and northeastern Queensland,Australia. Mycotaxon 129 (2), 329-359. Doi 10.5248/129.329

Morgado LN, Noordeloos ME, Lamoureux Y, Geml J. 2013 - Multi-gene phylogenetic analyses reveal species limits, phylogeographic patterns, and evolutionary histories of key morphological traits in Entoloma (Agaricales, Basidiomycota). Persoonia 31, 159-178.

Noordeloos ME. 1981 - Entoloma subgenera Entoloma and Allocybe in the Netherlands and adjacent regions with a reconnaissance of its remaining taxa in Europe. Persoonia 11, 153256.

Noordeloos ME. 1992 - Entoloma s.l. Fungi Europaei, vol. 5. Giovanna Biella, Italy.

Noordeloos ME. 2004 - Entoloma s.l. Fungi Europaei, vol. 5a. Edizione Candusso, Italy.

Noordeloos ME, Gates GM. 2012 - The Entolomataceae of Tasmania. Fungal Diversity Research Series 22, 1-400.

Noordeloos ME, Weholt Ø, Bendiksen E, Brandrud TE et al. 2018 - Entoloma aurorae-borealis sp. nov. and three rare Entoloma species in the Sinuatum clade (subg. Entoloma) from northern Europe. Sydowia 70, 199-210. 